\title{
PERAN GURU PENDIDIKAN AGAMA KRISTEN DALAM MEMBENTUK KARAKTER SISWA DI ERA INDUSTRI 4.0
}

\author{
Augusni Hanna Niwati Telaumbanua \\ SMA Negeri 1 Gunung Sitoli \\ augusni.hanna@gmail.com
}

\begin{abstract}
In this paper the authors reveal the role of Christian Religious Education in shaping the character of students in the era of the industrial revolution 4.0, becoming a new "world" for human life that has a broad impact on the structure of human life, including Christian education. By looking back at the role of Christian Religious Education, this paper emphasizes that Christian Religious Education is a forum for the formation and nurturing of student character so that one day they can become individuals with Christian character who can voice God's truth amid various problems faced. Besides, this also shows part of the role of Christian Religious Education in supporting the transformation of the character of the nation's children. Teachers have a major role in education which influences through teaching and modeling. The teacher's responsibility is to help students develop their potential to the fullest. The potential of students that must be developed does not only concern intelligence and skills but also all aspects of personality. Teachers are not only required to have an understanding or ability in the field of learning and learning but also in motivating students. Christian Religious Education Teachers (PAK) play a role in teaching spiritual values and motivating their students. PAK teachers must understand the concepts of motivation so that they can function as facilitators for the development of students, both in terms of intellectual, emotional, social, and mental-spiritual aspects.
\end{abstract}

Keywords : Role, Student Character, Industrial Era 4.0

\section{Pengantar}

\section{Arti dan Makna Pendidikan}

Pendidikan merupakan salah satu bagian terpenting dalam kehidupan manusia. Redja Mudyahardo (2001:3) menyatakan bahwa "Pendidikan adalah hidup, artinya segala pengalaman merupakan pendidikan yang berlangsung dalam segala lingkungan dan sepanjang hidup". Segala kegiatan yang dilakukan bernilai pendidikan dan berlangsung sepanjang hayat tanpa terbatas waktu. Samuel Sidjabat (1995:15) menyatakan bahwa istilah pendidikan dalam bahasa Latin menurut adalah $e d u$ care yang mengandung arti sebagai upaya sadar dan tersengaja untuk memperlengkapi seseorang, atau sekelompok orang, guna membimbingnya keluar dari satu tahapan (keadaan) hidup ke suatu tahapan hidup lainnya yang lebih baik. Dengan pengertian bahwa pendidikan membutuhkan proses yang dilakukan dengan suatu tujuan tertentu yang diharapkan. Dan hal ini dilakukan oleh seseorang yang bertanggung jawab baik secara pribadi maupun secara kelompok atau lembaga pendidikan.

Dalam Undang-Undang Sistem Pendidikan Nasional (Pasal 1 UU RI No. 20 Tahun 2003) dikatakan bahwa pendidikan adalah usaha sadar dan terencana untuk mewujudkan suasana belajar dan pro-ses pembelajaran agar peserta didik secara aktif mengembangkan potensi dirinya untuk memiliki kekuatan spiritual keaga- maan, pengendalian diri, kepribadian, kecerdasan, akhlak mulia, serta keterampilan yang diperlukan dirinya, masyarakat bangsa dan negara.

Berkaitan dengan itu pendidikan nilai sangat penting ditanamkan dan dikembangkan pada diri anak didik. Pengakuan dan penghargaan akan nilai-nilai kemanusiaan itu hanya akan timbul manakala ranah afektif dalam diri seseorang dihidupkan. Hal ini berarti dalam proses belajar mengajar perkem-bangan perilaku anak dan pemahamannya mengenai nilai-nilai moral seperti keadilan, kejujuran, rasa tanggung jawab serta kepedulian terhadap orang lain merupa-kan elemen yang tidak dapat dipisahkan dari unsur pendidikan.

Dalam ranah ilmu pengetahuan disebutkan bahwa pengetahuan haruslah mengandung tiga dimensi filosofis yaitu ontologi, epistemologi dan aksiologi (Samuel Sidjabat, 1995:15). Ontologi berkaitan dengan hakikat pengetahuan, sedang epistemologi menyinggung sumber pengetahuan, dan aksiologi bagian tugas menilai apa manfaat pengetahuan itu bagi kehidupan.

Hal ini juga ditegaskan oleh Socrates dalam Zaim Elmubarok (2008:3) bahwa pendidikan merupakan proses pengembangan manusia ke arah kearifan (wisdom), pengetahuan (knowledge) dan etika (conduct). Oleh karenanya membangun aspek kognitif, afektif dan psikomotor secara seimbang adalah nilai pendidikan yang 
paling tinggi. Demikian kegiatan Pendidikan Agama Kristen salah satu bagian dari pendidikan yang dimaksud.

\section{Tinjauan Literatur}

\section{A. Makna Pembelajaran PAK dan Pelaksanaannya}

PAK bukan hanya sekedar pemahaman tentang pengajaran agama Kristen secara ilmu pengetahuan (kognitif), tetapi kehidupan pribadi yang dapat dipraktekkan lewat sikap (afektif) dan perbuatan sehari-hari (psikomotor), sehingga melalui PAK orang Kristen semakin tumbuh dalam keteguhan iman dan kedewasaan rohani. PAK adalah usaha untuk menumbuhkembangkan kemampuan peserta didik agar dapat memahami dan menghayati kasih Allah dalam Yesus Kristus, yang dapat dinyatakan dalam kehidupan seharihari terhadap sesama, alam dan lingkungan hidupnya.

E.G. Homrighausen dan I.H. Enklar (1982:39), mengatakan: "Inilah arti yang sedalam-dalamnya dari PAK bahwa dengan menerima pendidikan itu, segala pelajar muda dan tua, memasuki persekutuan iman yang hidup dengan Tuhan sendiri, dan oleh dan di dalam Dia mereka terhisab pula pada persekutuan jemaatNya yang mengakui dan mempermuliakan nama-Nya di segala waktu dan tempat. Hal ini nyata dalam segala aktifitas dan tindakan sehari-hari menunjukkan karakter dan nilai-nilai kristiani yang baik demi kemuliaan nama Tuhan.

Pembelajaran PAK dalam prakteknya dilak-sanakan oleh Gereja dan lembaga pendidikan umum yang diberikan melalui mata pelajaran agama Kristen. Tugas ini merupakan panggilan yang di amanatkan oleh Tuhan Yesus Kristus yang disebut Amanat Agung yang tertulis dalam kitab Matius 28:19-20 berbunyi: "Karena itu pergilah, jadikanlah semua bangsa murid$\mathrm{Ku}$ dan baptislah mereka dalam nama Bapa dan Anak dan Roh Kudus, dan ajarlah mereka melakukan segala sesuatu yang telah Kuperintahkan kepadamu. Dan ketahuilah, aku menyertai kamu senantiasa sampai kepada akhir zaman". Tugas mengajar itu adalah mulia karena Tuhan Yesus sendiri merupakan seorang pengajar yang disebut Rabi atau Guru. Ia disebut Guru yang ideal karena apa yang dikatakannya adalah sesuai dengan yang dilakukan-nya. Menurut B.S. Sidjabat
(1993:178), tujuan tertinggi PAK adalah: "Membimbing peserta didik agar percaya dalam hati dan mengakui dengan mulut serta menyatakan dalam perilaku bahwa Yesus Kristus adalah Tuhan dan Juruselamat serta menuntun peserta didik untuk berakar dan bertumbuh dalam Kristus".

Penyelenggaraan PAK secara formal di sekolah dilakukan secara sadar, sengaja dan kontinyu serta mempunyai tujuan yang jelas. Tujuannya adalah menumbuhkembangkan sikap perilaku siswa yang berdasarkan nilai-nilai kristiani dan pengembangan spiritualitas dilakukan dengan menerapkan nilai-nilai pendidikan moral atau berkarakter sehingga dapat menghasilkan perilaku hidup sehari-hari dalam hubungannya dengan sesama dan lingkungan dimana ia berada.

Makna pendidikan Agama Kristen (PAK) tidak terlepas dari kesadaran dan kepekaan para pendidik bahwa kumpulan pengetahuan dan pengalaman umat manusia bukanlah satu-satunya ramuan untuk mengasuh peserta didik, sebab tugas pendidikan semestinya mencakup suatu pemahaman akan faktor-faktor dalam hubungan antar pribadi. Para guru yang baik, selalu sadar akan faktor-faktor demikian yang bekerja dalam tugas mengajar mereka, dimana konteks pendidikan di sekolah adalah lingkungan dimana peserta didik setiap generasi diajarkan tentang apa yang diharapkan dan dituntut kebudayaan hal ini menurut Iris V Cully (2006:1-2). Mewujudkan cita-cita pendidikan di atas, tidaklah terlepas dari pendidikan seperti apa yang diterima oleh peserta didik dan penerapan serta penghayatan akan nilainilai pendidikan itu sendiri. Perlu disadari bahwa peserta didik yang berpikir kritis, realistis dan sistematis serta bertanggung jawab tidak serta merta didapatkan. Sebab setiap manusia memiliki keunikan masingmasing yang membedakan satu dengan yang lain. Oleh sebab itu guru sebagai pembawa perubahan dan sekaligus pengembang karakter anak diharapkan bisa menyesuaikan pelaksanaannya untuk dapat mencapai tujuan pendidikan yang diharapkan.

\section{B. IPTEK dan Kehidupan Remaja}

Realita perkembangan ilmu pengetahuan dan teknologi dewasa ini telah memberi manfaat yang besar bagi kehidu- 
pan manusia, namun tanpa disadari dampak negatifnya telah merusak generasi penerus bangsa dan gereja.

Juga merebaknya isu-isu moral dikalangan remaja atau siswa dewasa ini seperti penggunaan narkoba, tawuran pelajar, pornografi, hubungan seksual, aborsi, pencurian, penipuan, minuman keras, merokok, menyontek, melawan orangtua atau guru di sekolah, tidak sopan dan lain sebagainya, sudah menjadi masalah kehidupan sosial dan dunia pendidikan. Kondisi ini sangat memprihatinkan masyarakat khususnya para orangtua dan para guru sebagai pendidik yang punya tanggung jawab besar. Akibatnyang ditimbulkan cukup serius dan tidak lagi dianggap suatu persoalan sederhana karena pelakupelaku dan korbannya adalah terutama para remaja atau siswa itu sendiri.

Para pelajar atau siswa khususnya usia remaja (umur 15-18 tahun) adalah mereka yang telah meninggalkan masa kanak-kanak yang penuh dengan ketergantungan dan menuju masa pembentukkan tanggung jawab. Masa remaja ditandai dengan pengalaman-pengalaman baru yang sebelumnya belum pernah terbayangkan dan dialami, baik bidang fisik biologis, maupun psikis atau kejiwaan. Pada saat seseorang berkembang secara fisik, sosial dan mental, maka perubahan ini akan mempengaruhi juga kehidupan spiritualnya.

Dengan perkembangan ilmu pengetahuan dan teknologi saat ini, telah mengubah cara pandang dan pola pikir siswa dalam menunjukkan identitasnya sebagai siswa/pelajar Kristen. Hal tersebut nampak dalam gaya hidup mereka mengikuti gaya hidup modern yang bertentangan dengan iman Kristen yaitu (Yuprieli Hulu, 2008:77-81):

a. Gaya hidup materialistis yakni pemahaman bahwa dasar dari segala sesuatu termasuk kehidupan manusia adalah alam kebendaan. Oleh sebab itu ditemukan beberapa siswa Kristen sekarang ini yang melakukan pencurian dan penipuan.

b. Gaya hidup hedonistis yakni pandangan bahwa kesenangan dan kenikmatan materi adalah tujuan hidup, sehingga muncul perasaan acuh tak acuh terhadap lingkungan sekitar yang ada diluar komunitas mereka. Oleh sebab itu ditemukan beberapa siswa
Kristen sekarang ini yang terlibat dalam narkoba, rokok, minuman keras, tawuran, seks bebas dan aborsi.

c. Gaya hidup individualistis yakni paham yang menganggap bahwa manusia secara pribadilah yang perlu diperhatikan. Oleh sebab itu ditemukan beberapa siswa Kristen sekarang ini yang tidak peduli dengan kepentingan orang lain, tidak mau menolong orang lain, bahkan sangat bebas untuk bersikap tidak sopan seperti pergaulan bebas.

d. Gaya hidup konsumeristis yakni gaya hidup yang suka menghabis-habiskan waktu dan uang untuk belanja berlebihan, bukan hanya benda tetapi juga makanan dan kesenangan. Oleh sebab itu ditemukan beberapa siswa Kristen sekarang ini yang melakukan penipuan dan pencurian, supaya dapat berbelanja pakaian yang mahal, membeli handphone yang mahal, laptop, dan juga berbagai makanan kesukaan mereka.

Pikiran yang semakin berkembang dan dipengaruhi dunia yang baru bahwa iman tidak dapat dipercaya atau tidak masuk akal. Untuk itu proses pembelajaran yang dilakukan oleh seorang guru kepada peserta didik diibaratkan sebagai tanaman yang harus terus menerus disirami dengan air sehingga dapat berakar lebih dalam, bertumbuh dengan segar, dan akhirnya menghasilkan buah (bdk. 1 Kor. 3:6).

Arus perkembangan teknologi menempatkan dunia saat ini dalam fase yang disebut sebagai Revolusi Industri 4.0 (Industrial Revolution/IR 4.0). Dengan perkembangan dari fase ke fase tentunya memberikan tantangan tersendiri bagi kehidupan sosial dan budaya. Di Indonesia baru sekitar dua dekade dunia internet merambah tanah air yang dapat dirasakan masyarakat luas. Hanya dalam beberapa tahun saja masyarakat begitu dimanjakan dengan gerakan jari yang dapat mengetahui informasi ke seluruh dunia, urusan keuangan, berbelanja, usaha, belajar dan segudang manfaat lainnya. Kita menemukan anak-anak begitu lincahnya berinteraksi dengan gadget, jauh lebih lincah dari kita yang usia paruh baya kebanyakan. (https://kominfo.go.id/content/detail/4286/pengguna-internet-indonesia-nomor 
-enam-dunia/0/sorotan_ media (diakses tanggal 2 Agustus 2018).

Hal ini didukung dengan laporan dari Asosiasi Penyelenggara Jasa Internet Indonesia (APJII) yang melaporkan bahwa dari populasi penduduk Indonesia sekitar 262 juta orang, pengguna internet di Indonesia mencapai lebih dari $50 \%$ atau sekitar 143 juta orang. Umumnya persentase usia terbesar pengguna internet adalah usia 19-34 tahun. Fase IR 4.0 disatu sisi memberikan hal positif, namun kehadirannya mem-berikan ancaman tersendiri bagi identitas dan keberadaan manusia sebagai makhluk sosial dan berbudaya. Lihat saja dengan mudah kita akan menemukan sekelompok orang yang duduk bersama melingkar, namun menyibukkan diri sendiri dengan "gawai" (gadget) dan bahkan justru sibuk berkomunikasi dengan indivi$\mathrm{du}$ yang secara visual hanya nampak dalam dunia maya, relasi sosial anak-anak juga cenderung menurun karena digantikan dengan game online yang jauh lebih menarik. (Fatimah Kartini Bohang "Berapa Jumlah Pengguna Internet Indonesia?", https://tekno.kompas.com/read/2018/02/22 /16453177/berapa-jumlah-pengguna-internet-indonesia (diakses 2 Agustus 2018).

Melihat kondisi demikian tentunya ini menjadi tantangan semua pihak, termasuk gereja dan pendidikan Kristen. Karena itu dalam tulisan ini, ingin berupaya untuk mempelajari terlebih dahulu revolusi industri 4.0 dengan dampak-dampaknya, khususnya dalam pendidikan dan konteks kehidupan manusia sebagai makhluk sosial. Dengan tantangan yang sangat kompleks, tentunya pendidikan Kristen membutuhkan fondasi kokoh untuk dapat memberitakan kebenaran sejati, karena itulah bahasan ini akan lebih melihat gagasan mandat profetik dalam pendidikan Kristen yang kemudian diharapkan dapat memberikan gagasan-gagasan yang menempatkan pendidikan Kristen tetap relevan dalam kemasannya untuk mendidik generasi demi generasi.

\section{Peranan Guru dalam Pembelajaran PAK}

Kegiatan belajar mengajar adalah suatu yang dengan sengaja diciptakan. Gurulah yang menciptakannya guna membelajarkan anak didik. Guru yang mengajar dan anak didik yang belajar. Di sana semua komponen pengajaran dipe-rankan secara optimal guna mencapai tujuan pengajaran yang telah ditetapkan sebelum pelajaran dilaksanakan. Demikian halnya dengan pembelajaran PAK adalah usaha sengaja, terencana dan berkelanjutan yang dilakukan oleh guru PAK dengan semua yang berkaitan dengan mata pelajaran PAK yang menyebabkan peserta didik mempelajarinya secara aktif, kreatif dan menyenangkan.

Sebagai kegiatan yang bernilai edukatif, belajar mengajar mempunyai hakikat, ciri dan komponen. Ketiga aspek ini harus diketahui dan dipahami oleh seorang guru guna menunjang tugas di medan pengabdian. Sebagai suatu sistem tentu saja kegiatan belajar mengajar mengandung sejumlah komponen yang meliputi tujuan, bahan pelajaran, kegiatan belajar mengajar, metode, alat dan sumber, serta evaluasi (Syaiful Bahri Djamarah, 2006:41). Tujuan pendidikan dan pembelajaran secara keseluruhan harus dikuasai oleh guru. Tujuan belajar adalah sejumlah hasil belajar yang menunjukkan bahwa siswa telah melakukan perbuatan belajar secara utuh baik aspek kognitif, afektif dan psikomotorik.

Namun dengan problem remaja yang ditemukan seperti yang diuraikan di atas tadi, merupakan krisis moral, akhlak (karakter) yang secara langsung atau tidak langsung berkaitan dengan pendidikan. Untuk itu perlu ditumbuh-kembangkan pendidikan karakter untuk membentuk kebiasaan hidup yang baik dan bijak serta mempraktekkannya dalam kehidupan sehari-hari.

Pikiran yang semakin berkembang dan dipenga-ruhi dunia yang baru bahwa iman tidak dapat dipercaya atau tidak masuk akal dapat menggoyahkan iman peserta didik. Untuk itu proses pembelajaran yang dilakukan oleh seorang guru kepada siswa diibaratkan sebagai tanaman yang terus menerus disirami dengan air sehingga dapat berakar lebih dalam, bertumbuh dengan segar dan akhirnya menghasilkan buah (bdk. 1 Kor. 3:6).

Di sinilah peranan guru PAK sangat penting, bukan hanya sebagai pengajar atau mentransfer ilmu pengetahuan saja tetapi bagaimana ia mendidik dan membimbing siswa sehingga mengalami perubahan hidup lebih baik akibat dari pembelajaran yang dilakukan. Dalam arti bahwa guru PAK sebagai pembimbing ke arah 
kedewasaan hidup yang lebih bermakna yang melaksanakan ajaran-ajaran agama Kristen berdasarkan Firman Tuhan dan berpusat pada Kristus sang guru Agung.

\section{Membangun Karakter Anak}

Karakter adalah tabiat, sifat-sifat kejiwaan, akhlak atau budi pekerti yang membedakan seseorang dengan yang lain, watak. Menurut Simon Philips, karakter adalah kumpulan tata nilai yang menuju pada suatu sistem, yang melandasi pemikiran, sikap dan perilaku yang ditampilkan. Sedangkan Doni Koesumo memahami bahwa karakter sama dengan kepribadian. Kepribadian dianggap ciri, atau karakteristik, atau gaya, atau sifat khas dari diri seseorang yang bersumber dari bentukan-bentukan yang diterima dari lingkungan, misalnya keluarga pada masa kecil, juga bawaan sejak lahir (Doni Koesoema, 2010:80).

Dengan pengertian di atas dapat dikatakan bahwa membangun karakter adalah proses mengukir atau memahat jiwa sedemikian rupa, sehingga berbentuk unik, menarik dan berbeda atau dapat dibedakan dengan orang lain. Namun secara umum karakter manusia dibagi atas 2 jenis yaitu karakter positif dan karakter negatif. Yang diharapkan dunia pendidikan adalah siswa yang berkarakter positif, namun karakter negatif siswa menjadi tantangan atau masalah dunia pendidikan. (Syaiful Bahri Djamarah, 2010:198)

Sebagaimana yang dikutip oleh Hamka Abdul Azis $(2011 ; 197)$ dalam bukunya Pendidikan Karakter Berpusat Pada Hati, dinyatakan bahwa karakter adalah kepribadian ditinjau dari titik tolak etis atau moral. Sebab pendidikan karakter adalah upaya penyiapan kekayaan batin peserta didik yang berdimensi agama, sosial, budaya, yang mampu diwujudkan dalam bentuk budi pekerti, baik dalam perbuatan, perkataan, pikiran, sikap, perasaan dan kepribadian.

Pendidikan karakter diharapkan diterapkan oleh seorang guru yang telah ditetapkan berdasarkan sumber agama, pancasila, budaya dan tujuan pendidikan nasional yaitu: religius, jujur, toleran, disiplin, kerja keras, kreatif, mandiri, demokrasi, rasa ingin tahu, semangat kebangsaan, cinta tanah air, menghargai prestasi, bersahabat/komunikatif, cinta damai, gemar membaca, peduli lingkungan/peduli sosial dan tanggung jawab. Inilah tanggung jawab para pendidik yang semestinya dipahami dan dimengerti dalam menjalankan tugasnya.

Senada dengan itu, Ratna Megawati sebagai salah satu pencetus pendidikan karakter di Indonesia telah menyusun karakter mulia yang selayaknya diajarkan kepada anak, yang kemudian disebut sebagai sembilan pilar yaitu: (Zaim Elmubarok, 2008;111)

1) Cinta Tuhan dan kebenaran (love Allah, trust, reverence, loyalit).

2) Tanggungjawab, kedisiplinan dan kemandirian (responsibility, excellence, self reliance, disciplene, orderliness).

3) Amanah (trustworthiness, reliability, honesty).

4) Hormat dan santun (respect, courtesy, obedience).

5) Kasih sayang, kepedulian dan kerjasama (love, compassion, caring, empathy, generousity, moderation, cooperation).

6) Percaya diri, kreatif dan pantang menyerah (confidence, assertiveness, resourcefulness, courage, determination and enthusiasm).

7) Keadilan dan kepemimpinan (justice, fairness, mercy, leadership).

8) Baik dan rendah hati (kindness, friendliness, humility, modesty).

9) Toleransi dan cinta damai (tolerance, flexibility, peacefulness, unity).

Di dalam kurikulum tingkat satuan pendidikan (KTSP), guru-guru memiliki peluang besar untuk menerapkan pendidikan karakter ke dalam masing-masing satuan pendidikan atau satuan mata pelajaran. Konsep pendidikan karakter terbaca dalam rumusan yang telah dibuat oleh $\mathrm{Ba}-$ dan Standar Nasional Pendidikan (BSNP) yaitu: pendidikan yang mengin-terasikan semua potensi peserta didik, pengetahuan, kepribadian, akhlak mulia serta keterampilan hidup mandiri dan dapat mengikuti pendidikan lebih lanjut.

Menurut Kemendiknas (2010:7), tujuan pendidikan karakter antara lain:

1) Mengembangkan potensi kalbu/ nurani/afektif peserta didik sebagai manusia dan warga negara yang memiliki nilai-nilai budaya dan karakter bangsa. 
2) Mengembangkan kebiasaan dan perilaku peserta didik yang terpuji dan sejalan dengan nilai-nilai universal dan tradisi budaya bangsa yang religious.

3) Menanamkan jiwa kepemimpinan dan tanggung jawab peserta didik sebagai generasi penerus bangsa.

4) Mengembangkan kemampuan peserta didik untuk menjadi manusia yang mendiri, kreatif dan berwawasan kebangsaan.

5) Mengembangkan lingkungan kehidupan sekolah sebagai lingkungan belajar yang aman, jujur, penuh kreatifitas dan persahabatan, serta dengan rasa kebangsaan yang tinggi dan penuh kekuatan (dignity).

Dari berbagai penjelasan di atas, dapat dipahami bahwa tujuan dari pendidikan karakter adalah membentuk, menanamkan, memfasilitasi dan mengembangkan nilai-nilai positif pada anak sehingga menjadi pribadi yang unggul dan bermartabat. Untuk mewujudkan tujuan pendidikan yang berkarakter dan bernilai mulia itu perlu pemantapan pendidikan yang diterimanya.

Demikian halnya dengan pembelajaran PAK yang optimal dan penerimaan siswa serta pemahaman nilai-nilai PAK sangat menentukan. Juga peranan pembinaan dari orangtua sebagai pendidik yang utama dari kehidupan seorang anak besar pengaruhnya. Untuk itu semua pihak ikut terbeban dalam mengajar, mendidik dan membina siswa menuju masa depan yang lebih cerah dan menjadi berkat bagi keluarga, masyarakat dan negara.

\section{Pembahasan}

\section{A. Tantangan Pendidikan di Era Revolusi Industri 4.0}

Revolusi industri menjadi satu momen sejarah yang memutar-balikkan kehidupan manusia, baik dalam sosial, ekonomi dan budaya. Revolusi industri pertama kali terjadi di abad 17-18 dimana dimulainya dengan penemuan mesin uap, yang kemudian hal ini mempengaruhi dalam bidang pertanian, pertambangan dan transportasi. Penggunaan mesin dalam manufaktur telah menggantikan tenaga hewan dan manusia yang selama ini menjadi sumber alat atau tenaga kerja dalam produksi, sehingga memberikan dampak signifikan dalam pendapatan masyarakat yang kemu- dian sangat berdampak atas aspek ekonomi, sosial, dan budaya. Revolusi industri kedua dimulai di awal abad 19 yang ditandai dengan produksi massal dan penemuan serta penggunaan listrik, yang juga kemudian disertai penemuan dan pengembangan pesawat, mobil, dan jaringan telepon. Setelah itu, sekitar tahun 1960-an, revolusi industri ketiga dimulai yang sering disebut sebagai revolusi komputer atau digital, hingga penemuan internet.

Dari perkembangan ketiga revolusi industri yang memiliki karakteristik masing-masing, maka saat ini dunia telah masuk dalam revolusi industri keempat. Istilah "Revolusi Industri 4.0" bermula dari ungkapan seorang ekonom Jerman yang merupakan pendiri World Economic Forum (WEF), yaitu Klaus Schwab. Dalam bukunya yang berjudul The Fourth Industrial Revolution, Klaus mengungkapkan bahwa:

"Mindful of the various definetions and academic arguments used to describe the first three industrial revolutions. I believe that today we are the beginning of a fourth industrial revolution. It began at the turn of this century and builds on the digital revolution. It is characterized by a much more ubiquitous and mobile internet, by smaller and more powerful sensors that have become cheaper, and by artificial intelligence and machine learning. (Klaus Schwab, 2016:1112)

Dalam IR 4.0 kita dapat menemukan dengan mudah perkembangan teknologi yang luar biasa, yang ditandai dengan artificial intelligence, Internet of Things (IoT) dan hyperconnectivity. Dalam masa ini, penggunaan robot semakin meluas untuk melengkapi kebutuhan hidup manusia, baik dalam pekerjaan, bisnis bahkan sampai urusan seks, misalnya robot seks yang merupakan produk artificial intelegence yang akan diproduksi massal oleh China (https://internasional .kompas.com/read/2018/02/02/16481301/robo t-seks-pintar-untuk-jomblo-dan-orangtuahadir-di-china). Di Indonesia sudah sangat familiar dengan bisnis online, baik dalam jual beli, promosi, transportasi, perbankan dan beragam fasilitas lainnya, semua 
sistem teknologi ini menggunakan koneksi data yang canggih.

a. Dampak Revolusi Industri 4.0 Bagi

Dunia Pendidikan

Dalam setiap perkembangan dan kemajuan, tentunya akan memberikan dampak, baik secara positif dan juga negatif. Dengan masuknya dunia dalam era revolusi industri 4.0, itu artinya dunia pendidikan sendiri perlu untuk masuk dalam belajar mengajar untuk mempersiapkan generasi di era ini. Dalam dunia digitalisasi di era ini tentunya disrupsi pendidikan telah merebak dalam teknologi pendidikan. Digitalisasi yang merubah data menjadi informasi telah mendisrupsi dunia pendidikan. Mesin pencari informasi menjadi sumber pembelajaran yang sangat kaya dan menyediakan beragam sumber pembelajaran, sehingga seorang peserta didik datang ke kelas sudah dengan beragam informasi yang telah dicari, ditemukan dan didengarnya.

Secara praktik dapat mengakses $e$ library yang berbayar ataupun gratis untuk dapat mengakses informasi data penelitian yang sangat kompleks dan sesuai kebutuhan. Artinya juga bawa semua orang dapat belajar dari informasi yang sama selagi masih memiliki akses terhadap informasi data tersebut. Mesin pencari informasi seperti google, sangat jauh lebih efektif dan efisien dalam memberikan informasi. Tentunya ini menjadi sebuah tantangan dalam dunia pendidikan dalam proses dan cara yang berbeda dengan yang selama ini ada dalam metode pembelajaran. Seorang peneliti dari UGM menyatakan bahwa:

"Kini guru tidak mungkin mampu bersaing dengan mesin dalam hal melaksanakan pekerjaan hafalan, hitungan, hingga pencarian sumber informasi. Mesin jauh lebih cerdas, berpengetahuan, dan efektif dibandingkan kita karena tidak pernah lelah melaksanakan tugasnya. Karena itu, fungsi guru bergeser lebih mengajarkan nilai etika, budaya, kebijaksanaan, pengalaman hingga empati sosial karena nilai-nilai itulah yang tidak dapat diajarkan oleh mesin. Jika tidak, wajah masa depan pendidikan kita akan suram." (Muhammad Nur Risal)

Menerima dan berbagi informasi pembelajaran yang sangat praktis didapatkan dengan biaya yang relatif murah, dan informasi itu dapat diperoleh tanpa memandang waktu dan kondisi, mengingat jaringan informasi data umumnya telah tersedia dimana-mana, sehingga seorang pembelajar tidak perlu datang ke kelas lagi. Jika demikian, bagaimana peran guru, apakah itu artinya profesi guru akan tergeser dan digantikankan dengan mesin pencari informasi? Dalam hal ini ternyata guru bukan lagi menjadi satu-satunya sumber informasi pembelajaran, seperti yang umumnya dan biasanya terjadi dalam proses belajar. Peserta didik yang telah memperoleh beragam informasi, tentunya membutuhkan bimbingan dan didikan dalam aspek lainnya, yaitu khususnya dalam pendidikan karakter. Dalam hal ini memang peran guru lebih menonjol pada peran sebagai mentor, fasilitator dan pembimbing. Perubahan dalam dunia pembelajaran inilah yang dinamakan sebagai disrupsi pendidikan.

Selain itu, Kemendikbud, juga memperingatkan tantangan revolusi industri ini dalam pendidikan dan pembinaan karakter anak bangsa. Dalam kesempatan peringatan Hardiknas 2018, ia menjelaskan bahwa:

"Dalam penguatan SDM tersebut terbentang tantangan internal dan eksternal sekaligus. Tantangan internal tampak pada gejala tergerusnya ketajaman akal budi dan kekukuhan mentalitas kita. Misalnya, belakangan ini kita melihat melemahnya mentalitas anak-anak kita akibat terpapar dan terdampak oleh maraknya simpul informasi dari media sosial. Untuk menjawab tantangan ini, sejak awal Kementerian Pendidikan dan Kebudayaan telah meneguhkan pentingnya penguatan pendidikan karakter dan literasi, selain ikhtiar mencerdaskan bangsa. Hal itu sejalan dengan revolusi karakter bangsa sebagai bagian dari pengejawantahan program Nawacita Presiden dan Wakil Presiden." (https://biroumum.kemdikbud.go .id/web/files/SAMBUTANMENDIKBUD-HARDIKNAS2018) 
b. Dampak Revolusi Industri 4.0 bagi

Pribadi dan Karakter

Disrupsi pendidikan secara positif mendorong sebuah model pembelajaran yang menempatkan peserta didik untuk memberdayakan segala potensi yang ada dan guru bertindak sebagai mentor. Namun disisi lain, disrupsi pendidikan ini juga memberikan dampak negatif yang begitu luas dan dalam untuk pencari data informasi. Di satu sisi adanya akses konten positif, dan disisi lain adanya akses konten negatif. Penggunaan digitalisasi komputer dan jaringan internet memberikan beragam kekayaan informasi namun juga dapat saja dilakukan plagiarisme yang umumnya dapat dengan mudah terjadi. Artinya hal ini menunjukkan bahwa integritas pengguna internet sangat dibutuhkan. Pribadi dan karakter individu membutuhkan fondasi yang kokoh sehingga mengabaikan kecurangan-kecurangan demikian.

Di sisi lain, interaksi dengan jaringan internet memang juga memberikan dampak sosial yang mendalam kepada indivi$\mathrm{du}$ "pecandu" dunia maya, yang merelakan banyak waktu berjam-jam untuk membangun interaksi didepan monitor komputer atau gadget, sehingga relasi sosial dalam keluarga dan masyarakat menjadi rapuh. Individu lebih memilih interaksi melalui monitor yang personalitas dan kenyamanan dapat lebih dinikmati dan tanpa relasi dalam kontak secara langsung. Hal ini melunturkan bangunan relasi dalam keberadaan sebagai manusia (human being) yang berstatus sebagai mahluk sosial. Dalam interaksi era ini sosial dibangun tanpa sekat ruang dengan daya jangkau seluruh dunia, namun relasi dalam lingkungan mengalami kekeroposan. Menanggapi perkembangan demikian, Johannes Oentoro (2011:46) menjelaskan bahwa, "Dalam teknokultur, wujud dan peranan asli manusia banyak diubah dan bahkan diobrak-abrik oleh teknologi. Penampilan dan perilaku manusia pun ikut berubah, artinya kemurnian manusia sebagai human being secara pasti mengalami kelunturan yang menjadi tantangan tersendiri."

"Technoference adalah interupsi teknologi (technological interruption) yang membuat anak menjadi lemah dalam kontrol emosi, sering gelisah, mudah frustasi, sering merengek dan merajuk lebih dari biasanya (situasi yang mirip ketika orangtua marah-marah karena koneksi wifinya sedang lemot padahal baru mau update status IG atau Facebook). Kondisi ini apabila tidak diatasi akan berlanjut menjadi kebiasaan dan karakter anak ketika tumbuh dewasa. Menurut Bambang Priyo Jatmiko (https://edukasi.kompas/2018/05/07.) penelitian tersebut hal ini terjadi karena lemahnya interaksi anak-ayah, dan anak-ibu disebabkan karena waktu anak berin-teraksi dengan orangtua jauh lebih sedikit daripada interaksi anak-smartphone dan orangtuasmartphone. Di sini juga muncul istilah "absent-presence", dimana orang-tua dan anak ada dalam satu ruangan, tapi tidak saling berinteraksi. Dalam hal ini sa-ngat penting memperbanyak waktu inte-raksi kita dengan anak-anak, termasuk in-teraksi dengan orang-orang di sekitar kita secara fisik dibandingkan interaksi kita dengan smartphone."

Disrupsi pendidikan sebagai dampak dalam revolusi industri 4.0 jelas berdampak pada perubahan perilaku dan karakter, pribadi dan sosial masyarakat. Hal ini memperlihatkan kebutuhan akan pendidikan yang mampu melahirkan generasi yang memiliki kepribadian dan karakter yang matang dan berintegritas, sehingga mengembalikan identitas dan status sebagai human being untuk dapat menyuarakan kebenaran atas permasalahan dalam dunia nyata.

\section{B. Pendidikan Agama Kristen Dalam Pembentukan Karakter Peserta Didik di Era Revolusi Industri 4.0}

E.G Homrighousen mengatakan bahwa "Pendidikan Agama Kristen berpangkal pada persekutuan umat Tuhan. Dalam Perjanjian Lama pada hakekatnya dasardasar terdapat pada sejarah suci purbakala. Pendidikan Agama Kristen mulai sejak terpanggilnya Abraham menjadi nenek moyang umat pilihan Tuhan, bahkan bertumpu pada Allah sendiri karena Allah menjadi pendidik bagi umatNya."

Istilah dalam bahasa Latin yang setara dengan pendidikan adalah "educare", yang berarti "merawat", memperlengkapi dengan gizi agar sehat dan kuat". Jadi, kata "educare" artinya "membimbing keluar dari". Dalam Ensiklopedi Pendidikan, secara umum pendidikan dapat diartikan sebagai "semua perbuatan dan usaha 
dari generasi tua untuk mengalihkan pengetahuan, pengalaman, kecakapan, serta ketrampilannya kepada generasi muda sebagai usaha untuk menyiapkan mereka agar dapat memenuhi fungsi hidupnya, baik jasmaniah maupun rohaniah". Penegasan itu menyatakan bahwa pendidikan merupakan usaha atau upaya sadar tujuan, atau bersahaja sehingga menuntut perencanaan, strategi, atau pendekatan.

Dalam Alkitab dinyatakan Allah bukan hanya Pendidik, melainkan juga Perencana dan Pelaksana proses pendidikan khusus dengan anak-anakNya, mulai dari penciptaan bumi dan isinya, termasuk menciptakan manusia, dan mengajarkan proses pendidikan kepada manusia. Pada masa Perjanjian Baru, Yesus menjadi fokus utama pendidikan. Dalam hal ini pendidikan yang dimaksud termasuk perihal belajar dan mengajar. Kata yang digunakan untuk menjelaskan belajar dan mengajar adalah: Pertama, didasko yang artinya "mengajar". Istilah ini paling banyak digunakan untuk menerangkan tentang tugas Yesus mengajar. Kedua, paideuo yang berarti "memberikan bimbingan, mengajar, melatih" (Kis.7:22). Ketiga, noutheteo yang berarti "mempertajam pikiran" (1 Kor 4:14). Keempat, katekeo yang berarti "mengemukakan informasi, menyampaikan fakta" (Luk.1:4). Kelima, matheteuo yang berarti "menjadikan murid" (Mat.28 :19). Keenam, oikodomeo yang berarti "membangun, membentuk" (1 Kor 3:9), dan Ketujuh, manthano berarti "belajar melalui praktik" (Ibr. 5:8).

Para pendidik pada masa Perjanjian Baru diawali oleh Yesus, kemudian dilanjutkan para Rasul dan jemaat mulamula. Yesus adalah Guru yang sempurna dan tidak ada bandingannya di dunia, dengan pengajaran-Nya luar biasa. Tanpa diminta oleh Yesus, banyak orang selalu berbondong-bondong mengikuti Dia ke mana pun Dia pergi (Mrk.1:22; 12:37).

Sebagai Guru Agung, Yesus memberi amanat kepada para murid-Nya untuk mengajar yang diperintahkan kepada mereka. Hal ini tampak jelas dalam Matius 28:1920, “... dan ajarlah mereka melakukan segala sesuatu yang telah diperintahkan kepadamu. Dan ketahuilah, Aku menyertai kamu senantiasa sampai kepada akhir zaman." Ayat ini merupakan dasar pendidikan bahwa setiap murid Yesus harus mengajarkan segala sesuatu yang Dia pe- rintahkan. Ayat ini merupakan mandat, yang dalam konteks umat Allah secara umum, "adalah menentang formalitas, menekankan kewajiban-kewajiban moral, mendorong perlunya pelayanan kerohanian, dan menyatakan perlunya hidup yang kudus bagi umat Allah".

\section{Peranan Pendidikan Agama Kris- ten dalam Pembentukan Karakter}

Melalui kitab Ulangan 6, keluarga Kristen diperingatkan akan tanggung jawabnya mewujudkan pendidikan umat Allah termasuk pendidikan karakter. Peran keluarga yang dimaksud adalah Ayah dan Ibu. Ulangan 6:4-9 diawali perintah Allah agar bangsa Israel melakukan dan memegang teguh segala perintah dan peraturan yang Allah berikan, disertai janji berkat jika mereka setia melakukannya (ayat 13). Perintah ini diberikan dalam kaitan persiapan mereka memasuki tanah Kanaan (ayat 3). Maksud dari perintah ini diberikan supaya bangsa Israel melakukannya ketika mereka masuk dan hidup di tanah Perjanjian sehingga mereka mampu menunjukkan keunikan sebagai umat Allah. Dalam tradisi Yahudi kata "syema" disebut sebagai "the fundamental truth of Israel's religion" and " the fundamental duty founded upon it." Maka Ulangan 6:49 merupakan patokan bagi keluarga Yahudi yang harus dilaksanakan. "Syema" merupakan merupakan inti dari pengakuan iman bangsa Israel. Dalam perkembangannya "syema" menjadi bagian penting bagi kehidupan bangsa Israel dan menjadi dasar bagi pendidikan kepada anak-anak mereka. Prinsip penting pendidikan anak berdasarkan Ulangan 6: pendidikan harus berkaitan dengan pengakuan bahwa Allah itu Esa, pendidikan harus dilakukan dengan serius, harus diajarkan di setiap kesempatan, harus diajarkan dengan prinsip keteladanan, pendidikan harus diberikan sejak anak-anak dan pendidikan adalah tanggung jawab orang tua. Karenanya, tidak ada satu orangtuapun yang dapat menghindar atau beralasan untuk tidak melakukan peran ini sekalipun dalam keterbatasan mereka (Sidjabat). Perlu diingat, banyak orang tua gagal dalam pendidikan karakter anak-anaknya karena kesibukan atau justru karena lebih mementingkan aspek kognitif saja.

Sebagai umat dan kepunyaan-Nya yang dikuduskan, Yesus mengutus para 
murid dan setiap orang percaya karena pemberitaan mereka (gereja, lembaga pendidikan Kristen dan orang percaya) untuk memberitakan kabar baik secara verbal dan nonverbal, dalam tindakan dan perkataan, untuk menjadi garam dan terang dalam semua aspek kehidupan umat manusia.

Tantangan teknokultural bagi generasi internet, telah membawa pada permasalahan pengacakan kepribadian, dimana tantangan teknokultural tersebut telah mengaburkan identitas diri sebagai hakekatnya manusia (Joeanes Oentoro, 2011:46), baik dalam pengembangan pribadi individu dan relasi sosial. Hal ini searah dengan apa yang dijelaskan oleh David F. Wells (2005:291) yang melihat bahwa generasi muda lebih menemukan nilai-nilai mereka ditempat-tempat hiburan, teman sebaya, film dan fantasi tayangan video yang menghias secara acak dunia batin, sehingga menjadi pribadi yang tidak lagi menemukan kebenaran obyektif untuk menentukan bagaimana kehidupan seha-rusnya dijalani.

Dalam kondisi dan situasi inilah kehadiran pendidikan Kristen dituntut menampilkan suatu pembeda dengan pendidikan pada umumnya. Secara hakiki pendidikan Kristen memiliki mandat untuk membawa para peserta didik mengenal kasih Kristus yang menjadi perpanjangan tangan Tuhan untuk memberitakan kasih Tuhan dan membawa peserta didik dalam pengenalan akan Tuhan sehingga mengalami pembaharuan identitas diri sebagai gambar Allah. Pendidikan Kristen dalam kebenaran injil yang akan menata kembali kepribadian dan karakter sebagai human being. Pendidikan Kristen menolong untuk seseorang mengalami pemulihan identitas diri, sehingga dapat membangun relasi dan kehidupan dengan sesama. Menyadari dirinya sebagai gambar Allah, ciptaan Allah dengan segala keunikan atributnya. Ini akan menolong seseorang untuk memiliki karakter yang ditransformasi dalam karya salib Kristus. Dengan identitas yang dipulihkan, maka seseorang akan sadar dan tahu apa yang akan menjadi respon terhadap permasalahan yang semakin bertumbuh subur.

Dengan pemulihan identitas diri, maka worldview peserta didik perlu dibangun kerangka pikir yang membentuk pemahaman tentang manusia seutuhnya. Se- hingga dapat mengenal dirinya sendiri dengan berbagai potensi yang telah Tuhan karuniakan, mengenal sumber kehidupan, dari mana dan untuk apa kehidupan? Dengan demikian peserta didik menemukan makna kehidupan dan mengetahui posisinya untuk dapat memberdayakan segala potensi yang telah Tuhan berikan. Hal ini merupakan fondasi untuk membangun identitas diri yang tangguh dalam diri seorang peserta didik supaya memiliki kematangan kepribadian dan karakter, sehingga mampu menyikapi secara bijak semua perkembangan tantangan teknologi di era saat ini.

Berdasarkan hakekat pembelajaran adalah suatu sistem belajar yang terencana dan sistematis dengan maksud agar proses belajar seseorang atau sekelompok orang dapat berlangsung sehingga terjadi perubahan yakni meningkatnya kompetensi pembelajaran tersebut. Demikian halnya dengan kompetensi pembelajaran PAK berlangsung sesuai dengan tuntutan kurikulum untuk dapat memperoleh hasil belajar siswa dalam perubahan.

Dalam kurikulum PAK seseorang dianggap kompeten apabila ia mampu menguasai ajaran imannya dengan mengintrepresentasikan, menganalisa dan melakukannya secara bertanggungjawab. Kompetensi dasar PAK yang diharapkan adalah: (Jasen Belandina Non-Serrano, 2009:29)

1) Menanggapi kasih Allah melalui keberadaan dirinya dengan mengasihi sesama manusia.

2) Mewujudkan sikap hidup yang dapat menunjukkan ibadah dan syukur kepada Allah.

3) Memelihara ciptaan Allah dalam hidup sehari-hari.

4) Menjelaskan karya Allah dalam dunia dan penyelamatan bagi manusia dan seluruh ciptaan-Nya.

5) Melakukan tindakan yang dapat menunjukkan tanggungjawab kepada Allah, diri sendiri, sesama dan alam lingkungan hidup.

6) Mewujudkan nilai-nilai Kristiani dalam kehidupan pribadi dan komunitas.

7) Menyampaikan berita damai dan menjadi pembawa damai sejahtera.

Materi atau bahan pelajaran untuk PAK dari tingkat dasar sampai menengah umum/kejuruan mengacu pada dua aspek, yaitu: hubungan timbal balik antara Allah 
dan manusia, serta hubungan manusia dengan sesamanya dan dengan lingkungan alam sekitar.

Proses pembelajaran PAK yang berbasis kompetensi adalah proses pembelajaran Kristiani yang diupayakan agar siswa mengalami sendiri pembelajaran melalui aktivitas-aktivitas kreatif yang difasilitas guru. Dengan harapan proses dan hasil pembelajaran memiliki bentuk-bentuk: karya, unjuk kerja dan perilaku atau sikap.

- Karya adalah bentuk dan bukti yang dialami dan dihasilkan siswa pada saat proses belajar berlangsung dan saat proses belajar berakhir.

- Unjuk kerja adalah bentuk yang dialami dan dihasilkan melalui belajar, yang ditampilkan oleh siswa merespon pembelajaran yang dialaminya.

- Perilaku/sikap adalah bentuk belajar dan hasil belajar yang dialami dan dihasilkan siswa atau proses penghayatan akan imannya melalui proses belajar, yang diwujudkan dalam bentuk tindakan konkret, nyata dan dapat dilihat mata maupun tidak dapat dilihat namun dapat dirasakan oleh orang lain dan membawa dampak positif bagi orang lain.

Nilai-nilai Kristiani menjadi suri teladan dan pegangan hidup dalam praktika sehari-hari sebagaimana layaknya orang Kristen sebagai pengikut Kristus yang membawa kehidupan kearah yang positif sesuai dengan sifat-sifat Kristus sebagai teladan. Hakikat nilai Kristiani sebagai dasar iman Kristen adalah nilai kerohanian. Nilai kerohanian dapat digambarkan sebagai terang dunia (Matius 5:14-16). Nilai itu dapat dilihat dari peran-peran aktif perilaku, perbuatan baik, tutur kata baik.

Nilai-nilai moral dari ajaran agama yang positif mempengaruhi siswa dan diwujudkan dalam bentuk sikap. Contoh: sikap jujur siswa dapat dilihat dan dialami dan dirasakan guru, mengasihi sesama dan ciptaan lainnya, sikap toleransi dalam bergaul walaupun memiliki banyak perbedaan, taat pada peraturan sekolah, disiplin dalam kehidupan sehari-hari, menjadi saksi bagi iman percayanya, peka menolong orang yang susah, mendoakan teman yang sakit dan lain-lain.

Dengan karya dan peranan Roh Kudus kita percayakan untuk melakukan pelayanan ini, dan tugas guru adalah menyelaraskan pengetahuan, unjuk kerja dan perilaku siswa, sehingga memperoleh proses dan hasil belajar yang utuh, yakni kesatuan pikiran, tindakan dan sikap yang nyata dalam praktek kehidupan seharihari.

Dalam pendidikan perlu diusahakan (Singgih D. Gunarsa, 1991:33):

1) Keselarasan pengajaran di sekolah dan di rumah sesuai dengan tujuan pendidikan.

2) Kesesuaian antara ajaran pendidikan dan perilakunya sendiri.

3) Dialog atau diskusi antara guru dengan murid mengenai nilai-nilai dan masalah-masalah mereka (bimbingan kelompok).

4) Latihan-latihan untuk membina berbagai perilaku yang diharapkan.

Dalam pelaksanaan PAK di sekolah, maka dibutuhkan yang namanya "disiplin". Sebab kasih tanpa disiplin dapat membawa anak ke dalam kehidupan manja atau sulit diatur, sedangkan disiplin tanpa kasih menuntun anak dalam kekerasan (B.S. Sidjabat, 2009:318). Sejalan dengan pendapat tersebut, Dr. Frithuzhug Dodson mengatakan bahwa dasar dari semua metode disiplin adalah membangun hubungan baik antara orangtua dan anak. Hubungan baik yang dimaksud adalah saling menyenangi dan menghormati, saling "menanggapi" dengan baik antara orang tua dan anak. Sayangnya, banyak orang tua yang menghiraukan premis psikologis yang dasar ini. Orang tua sering mengajukan perintah atau permintaan kepada anak-anaknya, hanya karena mereka merasa anak-anak harus patuh kepada mereka. Cara seperti ini, kata Dr. Frithuzhug, hanya membuat anak disiplin dalam beberapa waktu, tetapi tidak untuk selamanya. Bahkan, cara-cara seperti itu bisa menimbulkan rasa marah dan dendam dalam diri anak. Setelah prinsip "hubungan baik" dalam mendisiplinkan anak, maka masih ada beragam cara yang dapat dikembangkan sesuai dengan persoalan yang dihadapi, umur anak, dan hal-hal penting lainnya, berupa ungkapan pujian, pemberian barang, atau pemberian kemudahan tertentu (Fitzhugh Dodson, 1988:13).

Beberapa cara pendidikan dalam mengembangkan aspek moral anak:

1) Pendidikan berorientasi pada kasih sayang. Hubungan kasih sayang akan 
mendekatkan anak dengan orang tuanya atau pendidik, akan memudahkan orang tua/pendidik memberi hadiah dan hukuman yang sepadan.

2) Pendidikan berorientasi pada penalaran. Memakai aspek induksi dengan menjelaskan pada anak akibat dari perilaku yang ia lakukan. Dan ketegasan tanpa memakai cara kekerasan.

3) Pengawasan orangtua/pendidik melalui supervisi atau pengawasan. Pada masa remaja, kehangatan, bimbingan dan saran-saran sangat diperlukan.

4) Hukuman yang menunjukkan kuasa dan tidak memberikan kasih sayang. Menunjukkan kuasa artinya hukuman yang meliputi tidak memberi hak tertentu, mendesak dan mengancam, dengan catatan dilaksanakan secara tidak berlebihan atau tidak terus menerus. Menolak terhadap tingkah laku anak yang tidak diinginkan, cara ini menunjukkan ketidaksenangan orangtua/pendidik karena perbuatan anak yang tidak baik.

5) Behaviour training. Mencari cara yang efektif untuk mengubah perilaku anak yang tidak diinginkan atau perilaku prososial dengan cara:

a. Belajar langsung, memberi tanggung jawab atau tugas langsung.

b. Belajar secara tidak langsung, menyuruh mengajarkan sesuatu atau nilai-nilai kepada orang lain.

Agar pendidikan anak dapat berhasil baik di lingkungan keluarga atau sekolah sesuai dengan tujuan pendidikan yang diharapkan maka perlu dipahami bahwa setiap anak adalah pribadi yang khas dan unik. Anak memiliki ciri kepribadian, kemampuan dalam batas-batas tertentu.oleh karena itu seorang pendidik atau guru harus benar-benar menguasai cara dan metode yang tepat, serta mengenal dan memahami anak secara utuh.

Selain itu pembelajaran kontekstual perlu diperhatikan karena merupakan suatu konsep yang membantu guru mengaitkan isi pelajaran dengan situasi dunia nyata dan memotivasi siswa membuat hubungan antara pengetahuan dengan penerapannya dalam kehidupan mereka. Dengan demikian pembelajaran kontekstual terjadi dalam hubungan yang erat dengan pengalaman sesungguhnya dalam kehidupan sehari-hari.
Keaktifan peserta didik merupakan karakteristik dari model pembelajaran saat ini, hal ini dimungkinkan karena peserta didik telah memiliki banyak sumber pembelajaran yang dapat diperoleh dengan mudah melalui sumber data online. Dalam hal ini, Merril Ewert (2007:181) mengkategorikan ada empat model pendidikan Kristen, yaitu: Minimalist, Cloister, Activist, Engaged. Pertama, Minimalist dikategorikan sebagai institusi pendidikan Kristen yang rendah dalam refleksi dan rendah untuk bertindak. Dalam kategori ini, pendidikan Kristen berdalih memelihara keberadaan kekriste-nannya tetapi gagal untuk mengikutsertakan peserta didik dalam menguji komitmen inti iman mereka Kedua, Cloister mengutamakan pada refleksi. Mindset ini memfokuskan energi mereka untuk mempersiapkan peserta didik untuk masa depan melalui refleksi alkitabiah dan teologis. Memfokuskan perhatian terutama kepada keyakinan yang benar, selebrasi nilai-nilai inti, memelihara keagamaan dan identitas budaya, tetapi diskoneksi dari konteks sosialkultural. Intitusi demikian menolong peserta didik untuk menguji nilai-nilai inti, worldview dan merayakan fondasi kultural institusi (denominasi). Namun mereka sedikit sekali memperdulikan sebuah perjumpaan kesatuan untuk menjangkau yang lain atau melayani (Meril Ewert, 2007:182-183). Ketiga, Activist, kategori ini sangat aktif dalam tindakan pelayanan menjangkau masyarakat tetapi rendah dalam refleksi, untuk meluangkan waktu menguji keyakinan dan nilai-nilai kekristenan dan komitmen yang sebenarnya menjadi dasar pelayanan. Berpikir kritis dan refleksi pemikiran bukan menjadi karakteristik intitusi dalam kategori ini (Merrile Ewert, 2007:183). Keempat, Engaged "Person", intitusi yang menguji keyakinan dasar dan komitmen iman, dan kemudian dengan penuh tujuan melakukan pelayanan dan penjangkauan sebagai keunikan pemikiran Kristen. Peserta didik belajar untuk berpikir dalam kerangka kekristenan dan juga diikutsertakan mentor pengajar dalam penyelesaian masalah di masyarakat (Merril Ewert, 2007:185).

Tenaga pendidik merupakan pemegang mandat untuk memulihkan identitas anak didik. Guru adalah "orang tua kedua" anak didik yang memberi wawasan dan 
motivasi. Dalam kerangka inilah teori kolaborasi paling tepat digunakan. Disamping menunaikan tugas mulia sebagai pendidik ilmu umum maka guru sebagai tenaga pendidik juga harus bertindak sebagai orang tua yang membentuk karakter dan spiritualitas. Adapun tugastugas mulia pendidik, sebagai berikut: Pertama, mendampingi peserta didik dalam berbagai pergumulan dan permasalahan yang dihadapi. Kedua, bersedia menjadi konselor bagi peserta didik yang memiliki masalah. Ketiga, bersedia membimbing peserta didik dengan memberikan nasihat berdasarkan pada kebenaran firman Tuhan. Keempat, mengajari peserta didik supaya sungguh-sungguh meyakini Alkitab (Yohanes 8:31-32) sebagai kitab kehidupan. Kelima, mena-sehati peserta didik untuk menjalin perte-manan yang sehat.

Pendidikan Kristen memiliki panggilan untuk menyuarakan kebenaran. Tentunya cara menyerukan kebenaran da-lam konteks pendidikan bisa jadi sedikit berbeda dari bentuk pelayanan lainnya. Jika didalam fondasi kenabian, para nabi menyuarakan keadilan dan kebenaran dalam dimensi sosial politik pada masa itu lalu bagaimana relevansinya untuk masa kini? Terlebih lagi di era ini, lebih menekankan pada pembelajaran dengan model atau pendekatan heutagogi, yang menempatkan peserta didik sebagai pusat pembelajaran ditambah lagi dengan pengetahuan yang sudah digali informasinya oleh peserta didik dan dapat memperoleh data pembelajaran di luar kelas.

Komitmen iman dan terus merefleksikannya, memerlukan tindak lanjut dalam dunia nyata yaitu dalam tindakan. Dalam model dan kategori ini, Pendidikan Agama Kristen dimungkinkan untuk terealisasi, dimana pengajaran Kristen secara konsisten untuk pembaharuan spiritual dan juga pembaharuan keadilan sosial politik. Pembaharuan secara holistik juga akan berakibat pada pembaharuan holistik dalam masyarakat. Dalam pendidikan yang holistik menekankan kesatuan komitmen iman dan kemasyarakatan. Pendidikan Kristen yang menyuarakan kebenaran bukanlah pendidikan yang menggaungkan teriak kebenaran di ruang tertutup dan terisolir dalam cangkang kenyamanannya, namun memang pendidikan yang mengalami perjumpaan dengan masyarakat dan turut serta memecahkan permasalahan masyarakat dengan segala sumber daya dan komitmen iman dan keilmuan.

Dengan demikian peserta didik membutuhkan fondasi iman yang kokoh untuk terus merefleksikan komitmen iman dalam membangun kerangka tindakan di tengah masyarakat. Sehingga melalui komitmen iman dan kemasyarakatan, Pen-didikan Agama Kristen dapat mem-berdayakan seluruh potensi dan dayanya untuk menekuni penelitian-penelitianyang memang bermanfaat secara langsung bagi masyarakat dalam memecahkan perma-salahanpermasalahan sebagai wujud dari pendidikan Kristen.

Jika pendidikan agama Kristen telah diajarkan bahkan telah dijadikan mandat oleh Yesus kepada Rasul, untuk membentuk Karakter, moral, spiritual, lalu kita yang hidup dimasa kini, apa yang harus dilakukan? Sebagai umat dan kepunyaanNya yang dikuduskan, Yesus mengutus para murid dan setiap orang per-caya karena pemberitaan mereka (gereja, lembaga pendidikan Kristen dan orang percaya) untuk memberitakan kabar baik secara verbal dan nonverbal, dalam tindakan dan perkataan, untuk menjadi garam dan terang dalam semua aspek kehidupan umat manusia.

Disini, di tengah gempuran perkembangan teknologi di era revolusi industri, Pendidikan Agama Kristen berfungsi untuk menyuarakan kebenaran Allah sesuai dengan kapasitas dan bidang yang ada.

Kesetiaan lembaga pendidikan terhadap Injil akan menempatkan pendidikan Kristen untuk menempah peserta didik agar memiliki karakteristik spritualitas Kristen yang berdasarkan norma-norma dan perintah yang alkitabiah, sehingga secara individual bisa mengatasi dirinya untuk menjauh dari dosa dan kenakalankenakalan sosial, ketidakadilan, gerakan ektrimisme, radikal bisa diatasi. Kehidupan keluarga atau komunitas akan dapat dikritisi dari pada diafirmasi. Ini menegaskan bahwa bagaimana pendidikan Kristen bertindak sebagai yang mengasuh para reformator untuk menjadi pribadi-pribadi yang siap melakukan reformasi atas berbagai aspek kehidupan. Lembaga Pendidikan Kristen menjadi wadah pembentukan bagi para "nabi" yang memperlihatkan signifykansi dari pendidikan Kristen sebagai 
locus dalam melahirkan dan mengasuh nara didik sebagai reformator yang mampu menerangi dan menggarami seluruh aspek kehidupan di dunia ini.

Dalam model pendidikan Kristen, dalam kontek ini sekolah, lembaga perguruan tinggi dan lembaga pembelajaran lainnya memiliki peran untuk mempersiapkan peserta didik atau orang-orang muda agar memiliki Injil kebenaran sebagai pondasi kehidupan. Dalam mempersiapkan, mendidik dan melatih orang muda menjadi orang yang berkarakter rohani/alkitabiah maka James K.Smith mengatakan bahwa. "A Christian education provides "a Christian perspective" on the world, equipping young people to be successful but redemptive contributors to society precisely because they have been apprenticed in the disciplines and professions from the perspective of a Christian worldview." Dengan kata lain, Smith mau menegaskan perlu pemahaman perspektif Kristen secara utuh. Dengan demikian maka akan banyak orang muda yang bukan hanya memiliki ketrampilan dan pengetahuan namun juga memiliki worldview Kristen sehingga dapat melihat setiap vokasi dari prespektif Kristen. Hal inilah yang merupakan perwujudan dari pendidikan Kristen (Majalah Ilmiah Metode, $2019 \mathrm{http}: / /$ ojs.lppmmethodistmedan.net/).

\section{Keterlibatan Aktif Tenaga Pendi- dik/Guru dalam Pendidikan Agama Kristen}

Tantangan teknokultural bagi generasi internet, telah membawa pada permasalahan pengacakan kepribadian, dimana tantangan teknokultural tersebut telah mengaburkan identitas diri sebagai hakekatnya manusia, baik dalam pengembangan pribadi individu dan relasi sosial. Hal ini searah dengan apa yang dijelaskan oleh David F. Wells yang melihat bahwa generasi muda lebih menemukan nilainilai mereka di tempat-tempat hiburan, teman sebaya, film dan fantasi tayangan video yang menghias secara acak dunia batin, sehingga menjadi pribadi yang tidak lagi menemukan kebenaran obyektif untuk menentukan bagaimana kehidupan seharusnya dijalani.

Dalam kondisi dan situasi inilah kehadiran pendidikan Kristen dituntut menampilkan suatu pembeda dengan pendidikan pada umumnya. Secara hakiki para guru (tenaga pendidik) memiliki mandat untuk membawa para peserta didik mengenal kasih Kristus. Mereka menjadi perpanjangan tangan Tuhan untuk memberitakan kasih Tuhan dan membawa peserta didik dalam pengenalan akan Tuhan hingga mengalami pembaharuan identitas diri sebagai gambar Allah. Para guru sebagai pendidik akan menata kembali kepribadian dan karakter peserta didik sebagai human being. Guru sebagai pendidik harus menolong untuk seseorang mengalami pemulihan identitas diri, sehingga dapat membangun relasi dan kehidupan dengan sesama. Menyadari dirinya sebagai gambar Allah, ciptaan Allah dengan segala keunikan atributnya. Ini akan menolong seseorang juga untuk memiliki karakter yang ditransformasi dalam karya salib Kristus. Dengan identitas yang dipulihkan, maka seseorang akan sadar dan tahu apa yang akan menjadi respon terhadap permasalahan yang semakin bertumbuh subur.

Dengan memahami identitas sebagai "gambar" Allah, ini menjadi keyakinan esensial yang akan menolong untuk menyikapi perkembangan zaman, sehingga tantangan yang semakin pelik dan canggih tetap memiliki kebutuhan yang sama tentang keyakinan esensial. Disinilah signifikansi peran pendidikan agama Kristen yang bercorak profetik, yaitu membawa berita injil pertobatan. Karena itu Injil harus menjadi dasar membangun seluruh konsep pendidikan, supaya rahasia agung Injil dapat ditemukan peserta didik dalam seluruh proses pembelajaran. Dengan pemulihan identitas diri, maka worldview peserta didik perlu dibangun kerangka berpikir yang membentuk pemahaman tentang manusia seutuhnya. Sehingga dapat mengenal dirinya sendiri dengan berbagai potensi yang telah Tuhan karuniakan, mengenal sumber kehidupan, dari mana dan untuk apa kehidupan?. Dengan demikian peserta didik menemukan makna kehidupan dan mengetahui posisinya untuk dapat memberdayakan segala potensi yang telah Tuhan berikan. Hal ini merupakan fondasi untuk membangun identitas diri yang tangguh dalam diri seorang peserta didik supaya memiliki kematangan kepribadian dan karakter, sehingga mampu menyikapi secara bijak se- 
mua perkembangan tantangan teknologi di era saat ini.

Untuk itulah pendidikan agama Kristen memiliki fungsi yang menjadi sarana pengasuhan "bayi-bayi" yang kelak menjadi duta untuk menyuarakan mandat Kristus dalam segala aspek kehidupan dengan segala potensi, keahlian dan berbagai aspek yang telah ditanamkan oleh pendidikan agama Kristen. Searah dengan hal ini, George Knight ( mengatakan bahwa, "The conservative function of Christian Education is to provide a protected atmosphere for the nurturing of Christian youth, and an atmosphere in which all values, skills, and aspects of knowledge can be taught from the perspective of Christian philosophy" (Majalah Ilmiah, Vol 9 Nomor 3).

Dalam fungsi pengasuhan tersebut, artinya pendidikan holistik dan integratif merupakan model yang diterapkan. Tentunya ini akan menjadi tantangan tersendiri dalam menyikapi model pembelajaran jarak jauh (online learning) yang sudah banyak diterapkan di negara maju sebagai respon atas model pembelajaran heutagogi di era revolusi industri 4.0 ini. Dimana model pembelajaran ini lebih mengedepankan pada keaktifan siswa dalam pembelajaran mandiri dan bergelut dengan teks-teks melalui sumber pembelajaran online. Meresponi akan hal ini Starke menyatakan bahwa, "The study concludes that communications that are confined only to text can be dehumanizing"... The Christian life, in others word, can never be fully digitized." (Majalah Ilmiah, Vol 9 Nomor 3)

Karena itu Starke mengusulkan pentingnya kebutuhan sokongan pribadi yang mensupport dan mentor di lokal, untuk dapat menyediakan fondasi yang kuat bagi goal vokasi. Hal ini tidak mungkin tercapai jika dalam proses pembelajaran siswa tidak terlibat dalam pementoran untuk pemecahan masalah, dunia nyata. Tentunya ini menjadi pekerjaan rumah bagi lembaga pendidikan dan tenaga pendidik Kristen untuk tetap mempertahankan model pendidikan dan pembinaan yang holistik dan integratif, untuk menyediakan instrument pembelajaran yang memenuhi hal tersebut, baik dalam proses pembelajaran hingga assessment. Mengingat hal ini merupakan alternatif yang sudah dipertimbangkan dan dilakukan, namun mem- butuhkan kajian mendalam supaya proses pembelajaran mampu membawa peserta didik untuk memiliki kekuatan identitas diri, mengalami transformasi dan bukan sekedar pencarian aspek kognitif.

\section{Simpulan}

a. Karakteristik spiritualitas Pendidikan Agama Kristen adalah model klasik yang alkitabiah namun memiliki relevansi prinsip yang terus dibutuhkan dalam tantangan pendidikan saat ini. Tuntutan dan perubahan yang tak terelakkan menuntut pendidikan Kristen mampu memanifestasikan kerangka iman Kristen, sehingga kebenaran Injil yang mutlak dapat relevan dan kontekstual dalam kemasan kebutuhan saat ini. Pendidikan Agama Kristen dapat mempertahankan keunikannya sebagai pendidikan yang didasarkan dan dibangun dalam kerangka kebenaran Injil Yesus Kristus. Dengan mengimplementasikan Pendidikan Agama Kristen dalam semua aspek pembelajaran, maka pendidikan Kristen akan mampu membangun karakter peserta didik agar dapat mengenal identitasnya sebagai manusia yang adalah gambar Allah.

b. Pendidikan Agama Kristen sebagai sarana membangun sikap hati yang jujur dan amanah. Yang dimaksud dengan jujur adalah lurus hati atau tulus hati. Seseorang yang berpikir jujur berarti berpikir secara tulus dan ikhlas. Tugas adalah titipan berharga yang disampaikan kepada seseorang. Seseorang yang mendapat tugas berarti seorang yang layak dipercaya karena memiliki kompetensi andal untuk melakukan sesuatu.

c. Pendidikan AgamaKristen sebagai sarana membangun disiplin peserta didik. Yang dimaksud dengan disiplin ialah melakukan sesuatu sebagaimana mestinya dan tepat pada waktunya.

d. Pendidikan Agama Kristen sebagai sarana membangun sikap peserta didik untuk bekerja keras. Yang dimaksud dengan bekerja adalah pengerahan pikiran, emosi dan tenaga secara baik dan terkontrol dalam melakukan sesuatu, dengan demikian orang yang melakukannya akan mendapat hasil untuk dimanfaatkan dalam memenuhi 
kebutuhan dan meningkatkan taraf hidupnya.

e. Pendidikan Agama Kristen sebagai sarana membangun sikap peserta didik untuk mandiri. Mandiri artinya mampu berdiri sendiri, atau tidak selalu bergantung terhadap orang lain. Sehubungan dengan fungsinya, Pendidikan Agama Kristen harus mampu membangun sikap dan perilaku peserta didik untuk berdiri sendiri dalam mewujudkan tugas dan tanggung jawabnya terhadap Tuhan, diri sendiri, keluarga, gereja, masyarakat dan lingkungannya.

f. Pendidikan Agama Kristen sebagai sarana membangun sikap peserta didik menjadi kompetitif dan kooperatif. Pendidikan AgamaKristen dipanggil dan bertugas untuk membangun sikap peserta didik menjadi orang yang kompetitif sekaligus kooperatif. Artinya harus mampu membangun sikap yang mampu berkompetisi atau bersaing secara sehat dan mampu menjalani kehidupan secara bersama dan bekerja sama dengan yang lainnya.

g. Pendidikan Agama Kristen sebagai sarana membangun sikap peserta didik menjadi orang yang bertanggung jawab. Bertanggung jawab adalah sikap yang selalu siap melakukan dan melaksanakan tugas yang dipercayakan dan siap member respon terhadap masalah yang dihadapi. Oleh karena itu, untuk mewujudkan hal tersebut merupakan tugas dan tanggung jawab seorang guru PAK. Guru PAK memberikan jawaban terhadap tugas tersebut dengan cara melaksanakannya.

h. Guru Pendidikan Agama Kristen memiliki tugas yang sangat kompleks dan terpadu. Sebagai wujud nyata peranan guru PAK tersebut harus melaksanakan tugasnya dengan baik dan bertanggungjawab dalam mencapai tujuan pembelajaran yang sempurna. Salah satu tujuan Pendidikan Agama Kristen adalah siswa memiliki karakter yang baik seperti Tuhan Yesus Kristus. Sebab peran Guru Pendidikan Agama Kristen sangat berpengaruh terhadap pembentuk karakter siswa. Bahkan Alkitab memberikan keterangan bahwa Yesus memberikan we- wenang kepada para rasul, para nabi, para pengajar, para gembala dan para penginjil untuk mengajar dan membentuk karakter jemaat (siswa) menjadi dewasa dan sempurna (Efesus 4:11-16). Sebab itu, guru Pendidikan Agama Kristen perlu: 1) menjaga kekudusan hidupnya sebagai mitra Allah dalam membina, membimbing para muridnya menjadi murid yang berkarakter seperti Dia; 2) menyadari bahwa dirinya adalah hamba Tuhan, tugas mengajar merupakan panggilan Allah yang harus dikerjakan dengan sungguh-sungguh. Guru Pendidikan Agama Kristen harus mempersiapkan dirinya sebaik mungkin sebelum mengajar; 3) Guru Pendidikan Agama Kristen harus menjadi teladan bagi siswa serta bersahabat dengan siswa sebagai bagian dari pembentukan karakter siswa.

\section{Saran}

a. Sebagai seorang guru harus benarbenar menyadari tugas dan tanggung jawab sebagai seorang guru Pendidikan Agama Kristen, yang berbeda dengan guru secara umum. Artinya guru Pendidikan Agama Kristen selain mengajarkan ilmu pengetahuan, juga membimbing dan mendidik anak kepada pembentukkan sikap dan tingkah laku sehingga menjadi suatu kepribadian atau kebiasaan hidup anak yang berkarakter baik dan mencerminkan nilai-nilai Kristiani dalam praktek hidup sehari-hari.

b. Sebagai profesi seorang guru Pendidikan AgamaKristen, harus meneladani guru Agung Sang Teladan yaitu Tuhan Yesus sendiri. Ia mengajar penuh hikmat perhatian dan kasih sayang, selalu berusaha menolong mereka menjadi seorang penurut Firman dan takut akan Tuhan. Guru Pendidikan AgamaKristen harus lebih dulu menjadi contoh hidup dari pendidikan yang disampaikannya. Yesus disebut sebagai teladan karena apa yang diucapkannya sesuai dengan apa yang dilakukannya.

c. Hendaknya seorang guru Pendidikan Agama Kristen menyadari bahwa ia adalah seorang murid Kristus dan sekaligus sebagai seorang guru bagi muridnya. 
d. Menjadi seorang guru Pendidikan Agama Kristen hendaknya bukan karena terpaksa tetapi karena panggilan untuk melayani. Oleh sebab itu, Guru Pendidikan Agama Kristen terpanggil untuk menyampaikan suara Tuhan Allah kepada bangsa Indonesia, melalui kesaksian hidup yang benar, menjadi garam dan terang. Keterpanggilan tersebut, merupakan suatu bentuk kepedulian terhadap pertumbuhan dan perkembangan sumber daya insani/manusia Indonesia. Guru Pendidikan Agama Kristen harus memiliki keberanian membuat terobosan dalam banyak hal sehingga mampu membuat warga Gereja berubah menjadi "Manusia Baru". Manusia Baru yang mampu mengambil bagian serta ikut berperan aktif dalam memecahkan berbagai pergumulan, permasalahan pendidikan, sosial, budaya, hukum, politik dan keamanan bangsa Indonesia. Dan untuk mendapat warga Gereja yang demikian, Guru Pendidikan Agama Kristen wajib dan harus mempersiapkan - membina- membimbing muridmuridnya dengan berbagai program serta kegiatan belajar-mengajar.

\section{Ucapan Terima Kasih}

Pada kesempatan ini, penulis mengucapkan terima kasih kepada Redaktur yang telah memberikan masukan yang berharga sehingga tulisan dapat diterbitkan di Jurnal Institutio. Terima kasih juga kepada pengurus jurnal Institutio yang telah memberi ruang diskusi.

Penulis tidak dapat membalas semuanya, hanya doa yang tulus semoga segala kebaikan yang penulis dapatkan, dibalas oleh Tuhan dengan berkat kehidupan bagi kita semua.

\section{PUSTAKA ACUAN}

Azis, Hamka Abdul, Pendidikan Karakter Berpusat Pada Hati, Jakarta: AlMawardi Prima, 2011

Cully, Iris V., Dinamika Pendidikan Kristen, Jakarta: BPK GM, 2006

Djamarah, Syaiful Bahri, Strategi Belajar Mengajar, Jakarta: Rineka Cipta, 2006
Djamarah, Syaiful Bahri, Guru Dan Anak Didik Dalam Interaksi Edukatif, Jakarta: Rineka Cipta, 2010

Dodson, Fitzhugh, Mendisiplinkan Anak Dengan Kasih Sayang, Jakarta: BPK-GM, 1988

Elmubarok, Zaim, Membumikan Pendidikan Nilai, Bandung: ALFABETA, 2008

Ewert, Merril, Christian higher education: engaging society and Culture, Direction 36, no. 2: 175-191 (2007). ATLA Serials, Religion Collection, EBSCOhost.

Gunarsa, Singgih D., Psikologi Praktis, Anak Remaja dan Keluarga, Jakarta: BPK GM, 1991

Homrighausen, E.G. dan I.H. Enklaar, Pendidikan Agama Kristen, Jakarta: BPK GM, 1982

Hulu, Yuprieli, dkk.,Suluh Siswa 2: Berbuah dalam Kristus, Jakarta: BPK GM, 2008

Kemendiknas. Pengembangan Pendidikan Budaya Dan Karakter Bangsa, Jakarta: Puskur, 2010

Koesoema, Doni, Pendidikan Karakter: Strategi Mendidik Anak di Zaman Global, Jakarta: Grasindo, 2010

Mudyahardjo,Redja, Pengantar Pendidikan, Jakarta: Rajagratindo Persada, 2001

Non-Serrano, Jasen Belandina, Pedoman Bagi Guru PAK Melaksanakan Kurikulum Baru, Bandung: Bima Media Informasi, 2009

Oentoro, Johannes, Industri Pendidikan di Milenium Ketiga, Tangerang: UPH Press, 2011

Schwab, Klaus, The Fourth Industrial Revolution, Switzerland: World Economis Forum, 2016

Sidjabat, Samuel, Strategi Pendidikan Kristen, Yogyakarta: Yayasan ANDI, 1995

Sidjabat, B.S., Mengajar Secara Profesional, Bandung: Yayasan Kalam Kudus, 2009

Sidjabat, B.S., Membangun Pribadi Unggul suatu Pendekatan Telogis 
terhadap Pendidikan Karakter, Yogyakarta: Yayasan Andi, 2011

Wells, David F., Allah di Lahan Terbengkalai, terj. Surabaya: Momentum, 2005

\section{SUMBER LAINNYA}

https://kominfo.go.id/content/detail/4286/p engguna-internet-indonesia-nomorenam-dunia/0/sorotan_media (diakses tanggal 2 Agustus 2018)

Fatimah Kartini Bohang "Berapa Jumlah Pengguna Internet Indonesia?", https://tekno.kompas.com/read/201 8/02/22/16453177/berapa-jumlahpengguna-internet-indonesia (diakses 2 Agustus 2018).

https://internasional.kompas.com/read/201 8/02/02/16481301/robot-sekspintar-untuk-jomblo-dan-orangtuahadir-di-china

Muhammad Nur Rizal, Menghadapi Era Disrupsi, https://www.republika.co.id/berita/ jurnalismewarga/wacana/17/11/24/ozw64944 0-menghadapi-era-disrupsi, Pendiri Gerakan Sekolah Menyenangkan, Ketua Grup Riset Digital Literasi DTETI UGM.

https://biroumum.kemdikbud.go.id/web/fil es/SAMBUTAN-MENDIKBUDHARDIKNAS-2018

Bambang Priyo Jatmiko, Hardiknas, Ki Hadjar, dan Perilaku Orangtua Hadapi "Technoference" Revolusi Industri 4.0, https://edukasi.kompas/2018/05/ 07.

\section{MAJALAH ILMIAH METHODA}

Volume 9, Nomor 3, September Desember 2019 : 132-144; ISSN:2088-9534

http://ojs.lppmmethodistmedan.net/ 